Editorial

\title{
What the Transcriptome of the Eutopic Endometrium from Women with Endometriosis tells us about the Disease Pathophysiology: A Brief Reflection
}

\author{
Omero Benedicto Poli-Neto ${ }^{1}$ Juliana Meola ${ }^{1}$ Julio Cesar Rosa-e-Silva1이 \\ ${ }^{1}$ Department of Gynecology and Obstetrics, Division of \\ Gynecological Surgery, Faculty of Medicine, Universidade de \\ São Paulo, Ribeirão Preto, SP, Brazil
}

Rev Bras Ginecol Obstet 2020;42(10):593-596.

Endometriosis is characterized by the presence of endometriallike tissue outside the uterine cavity, usually represented by deep peritoneal, ovarian and/or infiltrative lesions ${ }^{1,2}$ and, more rarely, in extrapelvic sites. ${ }^{3}$ The estimated prevalence is of 5 to $10 \%$ of reproductive-age women ${ }^{4-6}$ despite the suggestion of an actual lower prevalence, of up to $1.8 \%$, in a recently published study based on a population of two million individuals. $^{7}$ The incidence, in turn, is more difficult to be estimated, but seems to be between 1.3 to 1.6 cases per 1,000 women in this same age group. ${ }^{8}$ Even considering this wide variation, if extrapolating to the Brazilian female population aged between 15 and 50 years estimated in the last census of 2010, there may be between 1 million and more than 5 million women with endometriosis, which is a very expressive number. Women with endometriosis may be asymptomatic or have varied symptoms, with the most frequent being pain (dysmenorrhea, dyskinesia, acyclic pain, dyspareunia) and infertility, followed by abnormal uterine bleeding and ovarian mass. ${ }^{9,10}$ Despite these associations, there are no clinical symptoms or signs that are good predictors of the disease, ${ }^{11,12}$ which culminates in the difficulty of an accurate clinical diagnosis. ${ }^{13}$ Other important aspects are the absence of a correlation between the severity of symptoms and extent of the disease, ${ }^{14}$ the presence of endometriosis in a reasonable number of asymptomatic women, ${ }^{15}$ and the lack of knowledge about the events determining the natural evolution of the disease, be it spontaneous progression or regression. ${ }^{16}$ Nonetheless, the disease is associated with a significant psychological and social impact, negative repercussions on the woman's quality of life ${ }^{17}$ and productivity, ${ }^{18}$ and relevant socioeconomic burden. ${ }^{19,20}$

Several theories have been proposed to explain the origin of the disease, among which are theories of retrograde menstruation (the most widespread and accepted), celomic metaplasia, lymphovascular metastasis, and, more recently, the theory of neonatal uterine bleeding. ${ }^{21,22}$ Although reasonable, by them- selves these theories do not explain the origin and evolution of the disease in all its nuances, and other factors need to be considered, such as: genetic, endocrine, immunological, inflammatory, and neuroangiogenic. Regardless of controversies, the eutopic endometrium in women with the disease definitely has peculiarities and a relevant role in the pathophysiological process of the disease. ${ }^{23-25}$ If we added genetic susceptibility ${ }^{26}$ and immune system dysfunction to this context, including autoimmunity and deficient immune surveillance, ${ }^{27-29}$ we would already have a plausible explanation for the question of why only some women develop the disease. Still, there would be another question: what would be or what would lead to this initial alteration of the eutopic endometrium? A potential explanation would be the presence of somatic mutations in the epithelial and/or stromal endometrial components. Despite their relevance to ovarian lesions (endometriomas), they do not appear to be crucial or significant in components of the eutopic endometrium. ${ }^{30}$ Another interesting element is the importance of endometrial progenitor cells, or endometrial stem cells in their broadest concept. However, although admittedly associated with the development of the lesion at ectopic sites, ${ }^{31}$ primary constitutive changes in these cells, when isolated from the eutopic endometrium, are still controversial. In this scenario of uncertainties about the triggering event of the first changes in the eutopic endometrium of women with endometriosis, it is worth discussing an equally interesting, although less explored, hypothesis of microbiological contamination. Some authors defend intrauterine microbial colonization as the trigger for pathophysiological events that culminate in endometriosis. ${ }^{32}$ Furthermore, infections can trigger cumulative genetic and epigenetic changes with the potential to trigger or maintain endometriosis. ${ }^{33}$ Although recently published, the concept of an initial eutopic endometrial infection followed by sterile inflammation has been proposed before. ${ }^{34}$ These propositions are
Address for correspondence Omero Benedicto Poli-Neto, MD PhD, Faculdade de Medicina, Universidade de São Paulo, Av. Bandeirantes, 3900, Vila Monte Alegre, Ribeirão Preto, SP, 14049900 , Brazil (e-mail: polineto@usp.br).
DOI https://doi.org/ 10.1055/s-0040-1713807. ISSN 0100-7203.
Copyright $\odot 2020$ by Thieme Revinter Publicações Ltda, Rio de Janeiro, Brazil

\section{License terms}

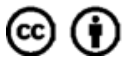


supported by the association between endometriosis and endometritis, ${ }^{13,35-39}$ by the microbial contamination observed in the uterine cavity and ectopic lesions, ${ }^{40-42}$ and by dysbiosis in the microbiome of the intestine and genital tract of women with endometriosis. ${ }^{43}$

Concomitant to these findings, the modernization of molecular biology techniques in recent decades has allowed great advances in understanding the processes involved in the evolution of several diseases. Currently, these methodologies are more affordable, easy to execute, and have good reproducibility. ${ }^{44,45}$ Transcriptome analysis, for example, is a direct reflection of gene expression in tissues. In this sense, the transcriptome analysis of the eutopic endometrium of women with endometriosis has an invaluable potential in contributing to understand local events associated with the condition. In fact, there are already relevant studies evaluating the transcriptome of the eutopic endometrium of women with and without endometriosis. ${ }^{46-50}$ However, some limitations are inherent to these studies, such as: reduced casuistry size; heterogeneous sample regarding phenotypic characterization, mainly of the menstrual cycle phase, the extent of the lesions, and associated symptoms; inadequate selection of healthy controls; non-optimized evaluation by the bioinformatics tools available; and redundancy in the interpretation of biological pathways, among others.

To try to remedy these limitations, our group conducted a meta-analysis including raw eutopic endometrial transcriptome data available in international databases from healthy women and from women with endometriosis. We restricted the control group to women with no known disease and stratified women with endometriosis into those with stages I and II disease and those with stages III and IV disease. For both groups, we considered the phase of the menstrual cycle, since it can interfere with the expression of the tissue transcriptome. ${ }^{51}$ By using some bioinformatics tools, we were able to predict the tissue microenvironment computationally, that is, we could infer the types of cells present in each sample. The method used can identify 64 cell types, including immune cells, stem cells, and stromal cells, among others. Thus, we observed that the eutopic endometrium of women with endometriosis in stages I and II has more proinflammatory characteristics than the endometrium of women in stages III and IV of the disease. Initial cases have a predominance of activated dendritic cells, effector memory CD4+ T-cells, eosinophils, type M1 macrophages and natural killer T-cells, which are typical of an inflammatory process induced by acute infections. In more advanced cases (stages III and IV), there is a predominance of M2 macrophages and natural killer T-cells. This last cell profile is characteristic of an antiinflammatory process, of tissue healing and repair ${ }^{52}$ present in late stages of infectious diseases ${ }^{53}$ that may be associated with the promotion of tumor growth. ${ }^{54}$ As for biological pathways, in women with endometriosis there is a direct involvement of the processes related to immune surveillance, stem cell self-renewal, and epithelium-mesenchymal transition. These mechanisms are already reported in the literature, but we note that pathways related to greater permissiveness of the immune system to cells in ectopic environments and imbalance between cell growth and survival $^{55}$ are more evident in advanced disease. Anyway, the predominance of different cell types added to the interaction between genes and the predominant biological pathways in each condition, regardless of the phase of the menstrual cycle, indicates that the eutopic endometrium of women affected by endometriosis has peculiar characteristics of a tissue that suffered or has been suffering some harm, aggression, or stress caused by an external, potentially microbiological agent.

Based on what was briefly mentioned above, thinking about an initial endometrial aggression, possibly by a microbiological agent, sustained for a variable period of time, and followed by the induction of genetic and epigenetic changes in the tissue and consequent self-sustained inflammation (sterile or not), all occurring in a genetically susceptible woman, whose immune system behaves anomalously and is permissive to the presence of endometrial cells (especially stem cells) in ectopic environments, would be an at least plausible hypothesis and justify further investigations. However, studies must be conducted to resolve limitations that may skew the results obtained, especially a good phenotypic characterization of patients and a good selection of healthy controls.

\section{Conflict of Interests}

The authors have no conflict of interests to declare.

\section{Acknowledgments}

We thank the Coordination for the Improvement of Higher Education Personnel (CAPES in the Portuguese acronym) for the support to our postgraduate program.

\section{References}

1 Agarwal N, Subramanian A. Endometriosis - morphology, clinical presentations and molecular pathology. J Lab Physicians. 2010;2 (01):1-9. Doi: 10.4103/0974-2727.66699

2 Nisolle M, Donnez J. Reprint of: Peritoneal endometriosis, ovarian endometriosis, and adenomyotic nodules of the rectovaginal septum are three different entities. Fertil Steril. 2019;112(04, Suppl 1):e125-e136. Doi: 10.1016/j.fertnstert.2019.08.081

3 Andres MP, Arcoverde FVL, Souza CCC, Fernandes LFC, Abrão MS, Kho RM. Extrapelvic endometriosis: a systematic review. J Minim Invasive Gynecol. 2020;27(02):373-389. Doi: 10.1016/j.jmig.2019.10.004

4 Cramer DW, Missmer SA. The epidemiology of endometriosis. Ann N Y Acad Sci. 2002;955(01):11-22, discussion 34-36, 396-406. Doi: 10.1111/j.1749-6632.2002.tb02761.x

5 Giudice LC, Kao LC. Endometriosis. Lancet. 2004;364(9447):1789-1799. Doi: 10.1016/S0140-6736(04)17403-5

6 Fuldeore MJ, Soliman AM. Prevalence and symptomatic burden of diagnosed endometriosis in the United States: national estimates from a cross-sectional survey of 59,411 women. Gynecol Obstet Invest. 2017;82(05):453-461. Doi: 10.1159/000452660

7 Eisenberg VH, Weil C, Chodick G, Shalev V. Epidemiology of endometriosis: a large population-based database study from a healthcare provider with 2 million members. BJOG. 2018;125 (01):55-62. Doi: 10.1111/1471-0528.14711

8 Owings MF, Kozak LJ. Ambulatory and inpatient procedures in the United States, 1996. Vital Health Stat 13. 1998;(139):1-119

9 Sinaii N, Plumb K, Cotton L, Lambert A, Kennedy S, Zondervan K, et al. Differences in characteristics among 1,000 women with 
endometriosis based on extent of disease. Fertil Steril. 2008;89 (03):538-545. Doi: 10.1016/j.fertnstert.2007.03.069

10 Schliep KC, Mumford SL, Peterson CM, Chen Z, Johnstone EB, Sharp HT, et al. Pain typology and incident endometriosis. Hum Reprod. 2015;30(10):2427-2438. Doi: 10.1093/humrep/dev147

11 Nnoaham KE, Hummelshoj L, Kennedy SH, Jenkinson C, Zondervan KT; World Endometriosis Research Foundation Women's Health Symptom Survey Consortium. Developing symptombased predictive models of endometriosis as a clinical screening tool: results from a multicenter study. Fertil Steril. 2012;98(03): 692-701.e5. Doi: 10.1016/j.fertnstert.2012.04.022

12 Surrey E, Carter CM, Soliman AM, Khan S, DiBenedetti DB, Snabes MC. Patient-completed or symptom-based screening tools for endometriosis: a scoping review. Arch Gynecol Obstet. 2017; 296(02):153-165. Doi: 10.1007/s00404-017-4406-9

13 Ballard KD, Seaman HE, de Vries CS, Wright JT. Can symptomatology help in the diagnosis of endometriosis? Findings from a national case-control study-Part 1. BJOG. 2008;115(11):1382-1391. Doi: 10.1111/j.1471-0528.2008.01878.x

14 Vercellini P, Fedele L, Aimi G, Pietropaolo G, Consonni D, Crosignani PG. Association between endometriosis stage, lesion type, patient characteristics and severity of pelvic pain symptoms: a multivariate analysis of over 1000 patients. Hum Reprod. 2007;22 (01):266-271. Doi: 10.1093/humrep/del339

15 Tissot M, Lecointre L, Faller E, Afors K, Akladios C, Audebert A. Clinical presentation of endometriosis identified at interval laparoscopic tubal sterilization: Prospective series of 465 cases. J Gynecol Obstet Hum Reprod. 2017;46(08):647-650. Doi: 10.1016/j.jogoh.2017.05.003

16 Hickey M, Ballard K, Farquhar C. Endometriosis. BMJ. 2014;348: g1752. Doi: 10.1136/bmj.g1752

17 Culley L, Law C, Hudson N, Denny E, Mitchell H, Baumgarten M, Raine-Fenning $\mathrm{N}$. The social and psychological impact of endometriosis on women's lives: a critical narrative review. Hum Reprod Update. 2013;19(06):625-639. Doi: 10.1093/humupd/ dmt027

18 Nnoaham KE, Hummelshoj L, Webster P, d'Hooghe T, Nardone FC, Nardone CC, et al; World Endometriosis Research Foundation Global Study of Women's Health consortium. Impact of endometriosis on quality of life and work productivity: a multicenter study across ten countries. Fertil Steril. 2011;96(02):366-373.e8. Doi: 10.1016/j.fertnstert.2011.05.090

19 Simoens S, Dunselman G, Dirksen C, Hummelshoj L, Bokor A, Brandes I, et al. The burden of endometriosis: costs and quality of life of women with endometriosis and treated in referral centres. Hum Reprod. 2012;27(05):1292-1299. Doi: 10.1093/humrep/ des073

20 Soliman AM, Taylor HS, Bonafede M, Nelson JK, Castelli-Haley J. Incremental direct and indirect cost burden attributed to endometriosis surgeries in the United States. Fertil Steril. 2017;107 (05):1181-1190.e2. Doi: 10.1016/j.fertnstert.2017.03.020

21 Zondervan KT, Becker CM, Koga K, Missmer SA, Taylor RN, Viganò P. Endometriosis. Nat Rev Dis Primers. 2018;4(01):9. Doi: 10.1038/s41572-018-0008-5

22 Zondervan KT, Becker CM, Missmer SA. Endometriosis. N Engl J Med. 2020;382(13):1244-1256. Doi: 10.1056/NEJMra1810764

23 Vinatier D, Cosson M, Dufour P. Is endometriosis an endometrial disease? Eur J Obstet Gynecol Reprod Biol. 2000;91(02):113-125. Doi: 10.1016/s0301-2115(99)00263-8

24 Carvalho L, Podgaec S, Bellodi-Privato M, Falcone T, Abrão MS. Role of eutopic endometrium in pelvic endometriosis. J Minim Invasive Gynecol. 2011;18(04):419-427. Doi: 10.1016/j.jmig.2011.03.009

25 Brosens I, Brosens JJ, Benagiano G. The eutopic endometrium in endometriosis: are the changes of clinical significance? Reprod Biomed Online. 2012;24(05):496-502. Doi: 10.1016/j. rbmo.2012.01.022

26 Rahmioglu N, Nyholt DR, Morris AP, Missmer SA, Montgomery $\mathrm{GW}$, Zondervan KT. Genetic variants underlying risk of endome- triosis: insights from meta-analysis of eight genome-wide association and replication datasets. Hum Reprod Update. 2014;20 (05):702-716. Doi: 10.1093/humupd/dmu015

27 Symons LK, Miller JE, Kay VR, Marks RM, Liblik K, Koti M, Tayade C. The immunopathophysiology of endometriosis. Trends Mol Med. 2018;24(09):748-762

28 Izumi G, Koga K, Takamura M, Makabe T, Satake E, Takeuchi A, et al. Involvement of immune cells in the pathogenesis of endometriosis. J Obstet Gynaecol Res. 2018;44(02):191-198. Doi: $10.1111 /$ jog.13559

29 Vallvé-Juanico J, Houshdaran S, Giudice LC. The endometrial immune environment of women with endometriosis. Hum Reprod Update. 2019;25(05):564-591. Doi: 10.1093/humupd/ dmz018

30 Suda K, Nakaoka H, Yoshihara K, Ishiguro T, Adachi S, Kase H, et al. Different mutation profiles between epithelium and stroma in endometriosis and normal endometrium. Hum Reprod. 2019;34 (10):1899-1905. Doi: 10.1093/humrep/dez155

31 Cousins FL, O DF, Gargett CE. Endometrial stem/progenitor cells and their role in the pathogenesis of endometriosis. Best Pract Res Clin Obstet Gynaecol. 2018;50:27-38. Doi: 10.1016/j. bpobgyn.2018.01.011

32 Khan KN, Fujishita A, Hiraki K, Kitajima M, Nakashima M, Fushiki S, Kitawaki J. Bacterial contamination hypothesis: a new concept in endometriosis. Reprod Med Biol. 2018;17(02):125-133. Doi: $10.1002 / \mathrm{rmb} 2.12083$

33 Koninckx PR, Ussia A, Tahlak M, Adamyan L, Wattiez A, Martin DC, Gomel V. Infection as a potential cofactor in the genetic-epigenetic pathophysiology of endometriosis: a systematic review. Facts Views Vis ObGyn. 2019;11(03):209-216

34 Kobayashi H, Higashiura Y, Shigetomi H, Kajihara H. Pathogenesis of endometriosis: the role of initial infection and subsequent sterile inflammation (Review). Mol Med Rep. 2014;9(01):9-15. Doi: 10.3892/mmr.2013.1755

35 Seaman HE, Ballard KD, Wright JT, de Vries CS. Endometriosis and its coexistence with irritable bowel syndrome and pelvic inflammatory disease: findings from a national case-control study-Part 2. BJOG. 2008;115(11):1392-1396. Doi: 10.1111/j.14710528.2008.01879.x

36 Takebayashi A, Kimura F, Kishi Y, Ishida M, Takahashi A, Yamanaka $A$, et al. The association between endometriosis and chronic endometritis. PLoS One. 2014;9(02):e88354. Doi: 10.1371/journal.pone. 0088354

37 Lin WC, Chang CYY, Hsu YA, Chiang JH, Wan L. Increased risk of endometriosis in patients with lower genital tract infection: a nationwide cohort study. Medicine (Baltimore). 2016;95(10): e2773. Doi: 10.1097/MD.0000000000002773

38 Cicinelli E, Trojano G, Mastromauro M, Vimercati A, Marinaccio M, Mitola PC, et al. Higher prevalence of chronic endometritis in women with endometriosis: a possible etiopathogenetic link. Fertil Steril. 2017;108(02):289-295.e1. Doi: 10.1016/j.fertnstert.2017.05.016

39 Tai FW, Chang CY, Chiang JH, Lin WC, Wan L. Association of pelvic inflammatory disease with risk of endometriosis: a nationwide cohort study involving 141,460 individuals. J Clin Med. 2018;7 (11):379. Doi: $10.3390 / j c m 7110379$

40 Khan KN, Kitajima M, Hiraki K, Yamaguchi N, Katamine S, Matsuyama $\mathrm{T}$, et al. Escherichia coli contamination of menstrual blood and effect of bacterial endotoxin on endometriosis. Fertil Steril. 2010;94(07):2860-3.e1, 3

41 Khan KN, Fujishita A, Masumoto H, Muto H, Kitajima M, Masuzaki $\mathrm{H}$, et al. Molecular detection of intrauterine microbial colonization in women with endometriosis. Eur J Obstet Gynecol Reprod Biol. 2016;199:69-75. Doi: 10.1016/j.ejogrb.2016.01.040

42 Leonardi M, Hicks C, El-Assaad F, El-Omar E, Condous G. Endometriosis and the microbiome: a systematic review. BJOG. 2020;127 (02):239-249. Doi: 10.1111/1471-0528.15916

43 Ata B, Yildiz S, Turkgeldi E, Brocal VP, Dinleyici EC, Moya A, Urman B. The endobiota study: comparison of vaginal, cervical and gut 
microbiota between women with stage 3/4 endometriosis and healthy controls. Sci Rep. 2019;9(01):2204. Doi: 10.1038/s41598019-39700-6

44 Lowe R, Shirley N, Bleackley M, Dolan S, Shafee T. Transcriptomics technologies. PLOS Comput Biol. 2017;13(05):e1005457. Doi: 10.1371/journal.pcbi.1005457

45 Chen L, Sun F, Yang X, Jin Y, Shi M, Wang L, et al. Correlation between RNA-Seq and microarrays results using TCGA data. Gene. 2017;628:200-204. Doi: 10.1016/j.gene.2017.07.056

46 Talbi S, Hamilton AE, Vo KC, Tulac S, Overgaard MT, Dosiou C, et al. Molecular phenotyping of human endometrium distinguishes menstrual cycle phases and underlying biological processes in normoovulatory women. Endocrinology. 2006;147(03):1097-1121

47 Burney RO, Talbi S, Hamilton AE, Vo KC, Nyegaard M, Nezhat CR, et al. Gene expression analysis of endometrium reveals progesterone resistance and candidate susceptibility genes in women with endometriosis. Endocrinology. 2007;148(08):3814-3826. Doi: 10.1210/en.2006-1692

48 Hever A, Roth RB, Hevezi P, Marin ME, Acosta JA, Acosta H, et al. Human endometriosis is associated with plasma cells and overexpression of B lymphocyte stimulator. Proc Natl Acad Sci U S A. 2007;104(30):12451-12456. Doi: 10.1073/pnas.0703451104

49 Crispi S, Piccolo MT, D’Avino A, Donizetti A, Viceconte R, Spyrou M, et al. Transcriptional profiling of endometriosis tissues identifies genes related to organogenesis defects. J Cell Physiol. 2013;228 (09):1927-1934. Doi: $10.1002 / j c p .24358$

50 Tamaresis JS, Irwin JC, Goldfien GA, Rabban JT, Burney RO, Nezhat $C$, et al. Molecular classification of endometriosis and disease stage using high-dimensional genomic data. Endocrinology. 2014;155(12):4986-4999. Doi: 10.1210/en.2014-1490

51 Poli-Neto OB, Meola J, Rosa-E-Silva JC, Tiezzi D. Transcriptome meta-analysis reveals differences of immune profile between eutopic endometrium from stage I-II and III-IV endometriosis independently of hormonal milieu. Sci Rep. 2020;10(01):313. Doi: 10.1038/s41598-019-57207-y

52 Mosser DM, Edwards JP. Exploring the full spectrum of macrophage activation. Nat Rev Immunol. 2008;8(12):958-969. Doi: $10.1038 /$ nri2448

53 Benoit M, Desnues B, Mege JL. Macrophage polarization in bacterial infections. J Immunol. 2008;181(06):3733-3739. Doi: 10.4049/jimmunol.181.6.3733

54 Galdiero MR, Garlanda C, Jaillon S, Marone G, Mantovani A. Tumor associated macrophages and neutrophils in tumor progression. J Cell Physiol. 2013;228(07):1404-1412. Doi: 10.1002/ jcp. 24260

55 Ersahin T, Tuncbag N, Cetin-Atalay R. The PI3K/AKT/mTOR interactive pathway. Mol Biosyst. 2015;11(07):1946-1954. Doi: 10.1039/c5mb00101c 